\title{
MENINGKATKAN KEPERCAYAAN DIRI SISWI MELALUI LAYANANAN BIMBINGAN KELOMPOK DENGAN TEKNIK SOSIODRAMA
}

\author{
${ }^{1}$ Dita Ayu Pratiwi, ${ }^{2}$ Arifin Nur Budiono, ${ }^{3}$ Fakhruddin Mutakin \\ ${ }^{1}$ Mahasiswa Prodi Bimbingan dan Konseling, FKIP, Universitas Islam Jember, Indonesia \\ ${ }^{2}$ Dosen Prodi Bimbingan dan Konseling, FKIP, Universitas Islam Jember, Indonesia \\ ${ }^{3}$ Dosen Prodi Bimbingan dan Konseling, FKIP, Universitas Islam Jember, Indonesia \\ Email: ditaayupratiwi28@gmail.com, budiononur05@gmail.com, fakhrudcounseling@gmail.com
}

\begin{abstract}
ABSTRAK
Kepercayaan diri merupakan kunci motivasi diri. Individu tidak akan menjalani hidup yang baik tanpa adanya kepercayaan diri. Peneliti melakukan observasi di MTs ASHRI Jember kelas VIII A tahun pelajaran 2017-2018 dan Hasil angket pretest yaitu 42\% yang mana merupakan tergolong pada kualifikasi kurang dan masih dibawah rata-rata kepercayaan diri yang ideal. Penelitian ini bertujuan untuk meningkatkan kepercayaan diri melalui layanan bimbingan kelompok dengan teknik sosiodrama. Jenis penelitian yang digunakan adalah penelitian tindakan bimbingan dan konseling (PTBK). Prosedur yang digunakan adalah model siklus. Berdasarkan hasil penelitian, pada pelaksanaan siklus I responden masih menunjukkan sikap kurangnya kepercayaan diri. Hal tersebut ditunjukkan dari tidak grogi ketika tampil di depan kelas, merasa yakin bahwa mereka bisa, berani dalam mengeksplore peran, dan tidak terlihat malu-malu hanya berkisar antara 50\%. Dan pada siklus II mulai terlihat peningkatan kepercayaan diri pada siswi hal ini terlihat dari tidak grogi ketika tampil di depan kelas, merasa yakin bahwa mereka bisa, berani dalam mengeksplore peran, dan tidakmalu-malu berkisar antara 75\%. Dengan demikian dapat disimpulkan bahwa layanan bimbingan kelompok dengan teknik sosiodrama dapat meningkatkan kepercayaan diri siswi kelas VIII A MTs ASHRI Jember.
\end{abstract}

Kata kunci : Kepercayaan diri, Sosiodrama

\begin{abstract}
Confidence is the key to self motivation. Individuals will not live a good life without any confidence. Researchers conducted observations in MTs ASHRI Jember class VIII A academic year 2017-2018 and the result of pretest is $42 \%$ which is classified in the qualification is less and still bellow the average of ideal confidence. This study aims to increase self confidence through group guidance services with sociodrama techniques. The type of research used is action research guidance and counseling (PTBK). The procedure used is the cycle model. Based on the result of research on the implementation of the cycle of I respondents still showed an attitude of lack confidence. It shown from not nervous when appearing in front of the class, feeling confident that they can, dare in eksplore role and do not look shy embarrassment that only around $50 \%$. And in the IInd cycle began to show an increasein confidence in student this is seen in not nervous when appearing in front of the class, feel confident that they can, dare in eksplore role and do not look shy embarrassment that only ranges between $75 \%$. Thus it can be concluded that the service of group guidance with sociodrama technique can improve self confidence of class VIII A MTs ASHRI Jember.
\end{abstract}

Keywords: Self confidence, Sociodrama. 


\section{PENDAHULUAN}

Menurut James O Lugo, kepercayaan diri merupakan ciri orang yang kreatif dan biasanya orang tersebut mendapatkan self assurance "keyakinan pada kemampuan sendiri". Bandura memberikan batasan pengertian kepercayaan diri sebagai suatu keyakinan seseorang bahwa dirinya akan dengan sukses mampu berperilaku seperti yang dibutuhkan agar sesuai dengan hasil yang diharapkan. Anthony (1992) berpendapat bahwa kepercayaan diri merupakan sikap pada diri seseorang yang dapat menerima kenyataan, dapat mengembangkan kesadaran diri, berfikir positif, memiliki kemandirian, memiliki kemampuan untuk memiliki dan mencapai sesuatu yang diinginkan.

Berdasarkan pengertian dari para ahli tersebut dapat disimpulkan bahwa kepercayaan diri merupakan keyakinan dengan kemampuan diri sendiri. Sikap percaya atas kemampuan diri dalam menghadapi berbagai hal serta rasa yakin bahwa dirinya dapat melakukan sesuatu hal sesuai dengan apa yang diharapkan.

Individu yang memiliki kepercayaan diri akan memahami apa yang ada pada dirinya, sehingga ia tahu dan paham tindakan apa yang akan dilakukannya untuk mencapai tujuan hidup yang diinginkannya. Individu yang memiliki kepercayaan diri dalam melaksanakan aktifitasnya selalu yakin bahwa dirinya mampu mengerjakan aktifitas tersebut dengan baik dan memberikan hasil yang optimal.

Pada penelitian ini, peneliti ingin mengetahui apakah Penggunaan Layanan Bimbingan Kelompok Dengan Teknik
Sosiodrama Dapat Meningkatkan Kepercayaan Diri Siswi di MTs ASHRI Jember Tahun Pelajaran 2017-2018. Tujuannya adalah untuk meningkatkan kepercayaan diri siswi MTs ASHRI Jember tahun pelajaran 2017-2018.

Prayitno (1995:178) mengemukakan bahwa Bimbingan kelompok adalah suatu kegiatan yang dilakukan oleh sekelompok orang dengan memanfaatkan dinamika kelompok. Artinya, semua peserta dalam kegiatan kelompok saling berinteraksi, bebas mengeluarkan pendapat, menanggapi, memberi saran, dan lain-lain sebagainya. apa yang dibicarakan itu semuanya bermanfaat untuk diri peserta yang bersangkutan sendiri dan untuk peserta lainnya.

Sementara Romlah (2001: 3) mendefinisikan bahwa bimbingan kelompok merupakan salah satu teknik bimbingan yang berusaha membantu individu agar dapat mencapai perkembangannya secara optimal sesuai dengan kemampuan, bakat, minat, serta nilai-nilai yang dianutnya dan dilaksanakan dalam situasi kelompok. Bimbingan kelompok ditujukan untuk mencegah timbulnya masalah pada siswa dan mengembangkan potensi siswa.

Dari beberapa pengertian bimbingan kelompok di atas, maka dapat disimpulkan bahwa bimbingan kelompok adalah Suatu kegiatan kelompok yang dilakukan oleh sekelompok orang dengan memanfaatkan dinamika kelompok yaitu adanya interaksi saling mengeluarkan pendapat, memberikan tanggapan, saran, dan sebagainya, dimana pemimpin kelompok menyediakan informasi-informasi yang 
bermanfaat agar dapat membantu individu mencapai perkembangan yang optimal.

Menurut Wiryaman (2000: 1-27) bahwa metode sosiodrama merupakan metode mengajar dengan cara mempertunjukan kepada siswi tentang masalah-masalah, caranya dengan mempertunjukan kepada siswi masalah bimbingan hubungan sosial tersebut didramatisirkan oleh siswi dibawah pimpinan guru.

Djamarah (2000:200) berpendapat bahwa metode sosiodrama adalah cara mengajar yang memberikan kesempatan anak didik untuk melakukan kegiatan memainkan peran tertentu yang terdapat dalam kehidupan masyarakat.

Dari berbagai penjelasan tentang sosiodrama diatas dapat diambil kesimpulan bahwa sosiodrama adalah sebuah teknik pemecahan masalah yang terjadi dalam konteks hubungan sosial dengan cara mendramakan masalahmasalah tersebut melalui sebuah drama.

Metode sosiodrama dan bermain peranan merupakan dua buah metode mengajar yang mengandung pengertian yang dapat dikatakan bersama dan karenanya dalam pelaksanaan sering disilih gantikan. Istilah sosiodrama berasal dari kata sosio atau sosial dan drama.

Kata drama adalah suatu kejadian atau peristiwa dalam kehidupan manusia yang mengandung konflik kejiwaan, pergolakan, benturan antara dua orang atau lebih. Sedangkan bermain peranan berarti memegang fungsi sebagai orang yang dimainkannya, misalnya berperan sebagai guru, anak yang sombong, orang tua dan sebagainya.
Kedua metode tersebut biasanya disingkat menjadi metode "sosiodrama" yang merupakan metode mengajar dengan cara mempertunjukkan kepada siswa tentang masalah-masalah hubungan sosial, untuk mencapai tujuan pengajaran tertentu.

Masalah hubungan sosial tersebut didramatisasikan oleh siswi dibawah pimpinan guru. Melalui metode ini guru ingin mengajarkan cara-cara bertingkah laku dalam hubungan antara sesama.

Jadi Metode Sosiodrama adalah metode pembelajaran bermain peran untuk memecahkan masalah-masalah yang berkaitan dengan fenomena sosial, permasalahan yang menyangkut hubungan antara manusia, seperti masalah kenakalan remaja, narkoba, gambaran keluarga yang otoriter, dan lain sebagainya. Sosiodrama digunakan untuk memberikan pemahaman dan penghayatan akan masalah-masalah sosial, serta mengembangkan kemampuan siswi untuk memecahkannya.

\section{METODE}

Penelitian ini diaplikasikan melalui penelitian tindakan bimbingan dan konseling (PTBK). PTBK merupakan suatu bentuk penelitian yang bersifat reflektif dengan melakukan tindakan tertentu agar dapat memperbaiki dan meningkatkan praktek pelayanan bimbingan dan konseling agar lebih profesional. Dalam hal ini, peneliti mencoba untuk mengetahui peningkatan kepercayaan diri siswi, setelah mendapatkan layanan bimbingan kelompok dengan teknik sosiodrama. 
Dalam pelaksanaan penelitian tindakan bimbingan dan konseling (PTBK) ini melalui dua tahapan siklus yang akan dilakukan oleh peneliti. Dalam siklus pertama maupun siklus kedua tahapantahapannya sama, yaitu terdiri dari perencanaan tindakan, pelaksanaan tindakan, pengamatan tindakan, dan refleksi. Siklus yang digunakan dalam penelitian ini adalah model Kemmis dan Mc Taggart.

Penelitian tindakan bimbingan dan konseling (PTBK) ini akan dilaksanakan dengan dua siklus untuk melihat dan meningkatkan kepercayaan diri siswi dengan menerapkan layanan bimbingan kelompok dengan teknik sosiodrama.

Dalam penelitian ini terdapat beberapa indikator yaitu: kepercayaan siswi meningkat, mampu mengembangkan potensi yang dimilikinya, berani mengemukakan pendapat, menjadi priabadi yang lebih baik serta berani bertanya kepada guru ketika proses belajar mengajar, dan menjadi siswi yang lebih aktif setelah responden mendapatkan bimbingan kelompok dengan teknik sosiodrama. Adapun indikator keberhasilan dari penelitian ini adalah apabila setengah atau 50\% dari responden mampu meningkatkan kepercayaan dirinya.

Variabel bebas pada penelitian ini adalah sosiodrama. Peneliti menyebut

\section{HASIL DAN PEMBAHASAN}

Penelitian

bertujuan

untuk mengetahui kadar peningkatan kepercayaan diri siswi sebelum mengikuti bimbingan kelompok dengan tehnik sosiodrama dan sesudah mengikuti. Pengumpulan data dimulai dengan sosiodrama sebagai variabel bebas karena dalam PTBK ini peneliti menggunakan sosiodrama sebagai alternatif yang akan digunakan untuk menekan problem yang terjadi pada objek penelitian.

Sedangkan variabel terikat pada penelitian ini adalah kepercayaan diri. Kepercayaan diri dikatakan sebagai variabel terikat karena penurunannya dapat dipengaruhi oleh dinamika kelompok yang diberikan oleh peneliti. Populasi pada penelitian ini adalah 28 siswi kelas VIII A MTs ASHRI Jember. Sedangkan sampel pada penelitian ini adalah 9 siswi MTs ASHRI Jemberkelas VIII A tahun pelajaran 2017-2018.

Teknik analisis data yang digunakan dalam penelitian ini adalahdengan menggunakan analisis data kualitatif yang memiliki kontribusi untuk menyimpulkan keberhasilan dan ketidakberhasilan penelitian. Menghitung persentase tingkat kepercayaan diri siswa disekolah (Anas Sudijono, 2004: 43) dengan rumus:

$P=\frac{X}{N} \times 100 \%$

Keterangan:

$\mathrm{P}=$ Besar persentase

$X=$ Jumlah skor yang di dapat

$\mathrm{N}=$ Jumlah skor maksimal

menyebarkan angket uji coba kepada 29 siswa kelas VIII A MTs. ASHRI dengan jumlah 40 soal. Kisi-kisi indikator soal angket dapat dilihat dilampiran, setelah semua jawaban terkumpul maka berdasarkan hasil angket seluruh siswi yang dapat dilihat pada lampiran. Hasil angket pretest yaitu $42 \%$ yang mana 
merupakan tergolong pada kualifikasi kurang dan masih dibawah rata-rata kepercayaan diri yang ideal. Para siswi masih banyak yang tidak percaya diri dangan diri mereka, dengan kemampuan yang dimiliki bukan hanya dalam konteks individu tapi juga terlihat dalam proses belajar mengajar. Kebanyakan siswi tidak percaya diri dan malu untuk bertanya kepada guru tentang dengan pelajaran yang belum mereka fahami akibatnya mereka menjadi bingung ketika diberikan tugas.

Banyak faktor yang melatarbelakangi kurangnya kepercayaan diri siswi kelas VIII A. Lingkungan sekolah sekaligus pondok juga mempengaruhi karena mereka merasa jauh dari keluarga, serta faktor ekonomi dan latar belakang keluarga merupakan faktor yang paling banyak dialami responden. Dan peneliti mengambil 9 siswi dengan nilai angket terendah untuk diberikan layanan bimbingan kelompok dengan tehnik sosiodrama.

Penelitian dibagi kedalam dua siklus bimbingan kelompok, siklus I diadkan sebanyak tiga pertemuan. Kegiatan sosiodrama dilakukan pada pertemuan kedua yaitu hari sabtu 13 Mei 2018 memainkan sosiodrama dengan judul "legenda situ begendit". Pada siklus I berdasarkan hasil angket dan presentse yang dapat dilihat dilampiran diketahui bahwa nilai prosentase dari $42 \%$ menjadi $49 \%$, berarti terjadi kenaikan sebesar $7 \%$. Kepercayaan diri meningkat sedikit, berdasarkan pengamatan peneliti siswi masih terlihat malu- malu serta kurang maksimal dalam memainkan peran sehingga masih perlu dilaksanakan siklus selanjutnya.

Siklus II dilaksanakan dengan tiga kali pertemuan, Dan kegiatan sosiodrama dilakukan pada pertemuan kedua yaitu pada tanggal 16 mei 2018 dengan tema sosiodrama "nilai kepedulian terhadap kebersihan". Dari hasil observasi dan angket siklus II dapat dilihat dilampiran diketahui ada peningkatan persentase sebesar $11 \%$ dari rata-rata persentase sebelum siklus II sebesar $49 \%$ menjadi $60 \%$. Dan pada siklus II analisis tindakan yaitu siswi tidak grogi ketika tampil didepan kelas, yakin bahwa mereka bisa, berani mengeksplore peran, serta tidak terlihat malu-malu.Setelah siklus II berdasarkan hasil pengamatan dan peningkatan kepercayaan diri 9 yang tadinya berada pada kualifikasi cukup menjadi baik. Dengan demikian penelitian menyimpulkan untuk tidak melanjutkan bimbingan ke siklus berikutnya karena sudah memenuhi kategori baik.

Dan pada tabel hasil angket pra siklus, siklus I, serta siklus II yang dapat dilihat pada lampiran terlihat adanya peningkatan kepercayaan diri siswi kelas VIII A. Jadi kegiatan bimbingan kelompok dengan teknik sosiodrama mempengaruhi kepercayaan diri siswi kelas VIII A .

\section{SIMPULAN}

Setelah peneliti melakukan proses pengumpulan data, pengolahan dan pembahasan dalam bab sebelumnya, maka dapat ditarik kesimpulan bahwa layanan bimbingan kelompok dengan teknik sosiodrama dapat meningkatkan kepercayaan diri siswi kelas VIII A MTs. ASHRI Jember. 


\section{DAFTAR PUSTAKA}

Alsa, Asmadi dkk. 2006. Hubungan Antara Dukungan Sosial dan Orang Tua dengan Kepercayaan Diri Remaja Cacat Fisik. Semarang: Jurnal Psikologi

Angelis B. 2003. Percaya Diri Sumber Sukses dan Kemandirian. Terjemahan Baty Subakti. 2001. Jakarta: PT.Gramedia Pustaka Utama

Desmita. 2016. Psikologi Perkembangan Peserta Didik. Bandung: PT Bumi Aksara

Djamarah, S.B. \& Zain.A. 2010. Strategi Belajar Mengajar. Jakarta: Rineka Cipta

Drajat Zakiah. 1995. Kesehatan Mental.Jakarta: CV. Haji Masagung

Djannah, Wardatul, Yulita W.A.N, Ayom. 2012. "Teknik Sosiodrama Untuk Meningkatkan Kepercayaan Diri Siswa Kelas VIII B SMP Kristen 1 Surakarta Tahun Pelajaran 2011/2012".jurnal.fkip.uns.ac.id

Hakim.2002. Mengatasi Rasa Percaya Diri. Jakarta: Puspa Swara

Hartinah DS, Sitti. 2009. Konsep Dasar Bimbingan Kelompok. Bandung : PT Refika Aditama

Hurlock, E. $1980 . \quad$ Psikologi Perkembangan.Jakarta: Erlangga
Hobri. 2007. "Metodologi Penelitian". Jakarta: PT. Bumi Aksara.

Khairani Makmun. 2014. Psikologi Konseling. Yogyakarta: PT Rineka Cipta

M Mufarohah. 2013. etheses.uinmalang.ac.id/1781/5/09410125_Bab _2.pdf

M Shalahuddin 2014. jurnalki.uinsby.ac.id/index.php/jurnal ki/article/view/14/9

Nur Budiono, Arifin. 2015. Buku Pedoman Penyusunan Proposal dan Skripsi. Jember: Pustaka Radja

Sarastika pradipta. 2014. Stop Minder dan Grogi. Yogyakarta: Araska

Santrock, J. W. 2004. Educational Psychology 2nd Edition.New York: Mccrwhill

Sanjaya Wina. 2007. Strategi Pembelajaran Berorientasi Pendidikan. Jakarta: Kencana Presada Media Group.

Sutirna. 2013. "Bimbingan dan Konseling". Yogyakarta: CV. Andi Offse

Virgin. 2011. "Teknik sosiodrama dan psikodrama". http://misscounseling.blogspot.com/ 2011/03/tehnik-sosiodrama-danpsikodrama.

Wingkel .2004. "Bimbingan dan Konseling di Institusi Pendidikan". Jakarta: PT. Gramedia 